\title{
PENGARUH PERTUMBUHAN EKONOMI, PENGELUARAN PEMERINTAH DI SEKTOR PENDIDIKAN DAN KESEHATAN TERHADAP KEMISKINAN DI PROVINSI ACEH
}

Cut Putri Mellita Sari ${ }^{\text {a1 }}$, Mhd. Nurdin ${ }^{\text {a2 }}$

${ }^{a}$ Fakultas Ekonomi dan Bisnis Universitas Malikussaleh

1Corresponding author: cmellita0674@gmail.com

2 mhdnurdin27@gmail.com

\section{ARTICLE INFORMATION ABSTRAC}

Keywords: Economic Growth, Government Expenditures in the Education and Health Sector, Poverty
This study aims to determine the effect of economic growth, government spending in the education and health sectors on poverty in the Province of Aceh in the year. The data used in this study are secondary data. The data analysis method used in this study is the Multiple Linear Regression model. The results of the study show that partially the economic growth variable does not have a positive and significant effect on poverty in Aceh Province. And government expenditure variables in the education and health sectors negatively and significantly affect poverty in Aceh Province. While simultaneously the variables of economic growth and government expenditure in the education and health sectors have a positive and significant effect on poverty in the Aceh Province in the year.

\section{PENDAHULUAN}

Menurut (Sukirno, 2008) Kemiskinan merupakan salah satu bentuk kesenjangan dalam kehidupan untuk memenuhi kebutuhan dalah keseharian ataupun kebutuhan dasar seperti makanan, pakaian, tempat yang layak untuk bertempat tinggal, pendidikan, dankesehatan.

Bermula dari hanya ketidakmampuan mencukupi keperluan seperti kebutuhan dasar dan memperbaiki keadaan hingga pengertian yang lebih luas yang memasukkan unsur-unsur social dan moral.

Pada hasil publikasi BPS RI pada juli 2017 lalu menunjukkan Provinsi Aceh mendapatkan predikat sebagai provinsi dengan jumlah kemiskinan tertinggi di sumatera. "Secara nasional, Aceh berada di peringkat ke-enam termiskin setelah papua, papua barat, maluku, NTT, dan gorontalo dan ini menjadi masalah sedangkat pertumbuhan ekonomi membaik, apakah pertumbhan ekonomi tidak berpegaruh untuk mengurangi kemiskinan.

Dan pada dasarnya juga dengan pengeluran pemerintah di anggap juga sangat penting dalam mempengaruhi kemiskinan terutama pengeluaran pemerintah di sektor pendidikan dan kesehatan, karena pengeluaran pemerintah merpakan salah satu indikator atau aspek penggunaan sumber daya ekonomi melalui pembayaran pajak, dan juga pengeluaran pemerintah pada sektor pendidikan dan keshatan merupakan bisa dikatakan sebuah komposisi yang diperlukan dalam Indeks Pembangunna Manusia. Pengeluaran pada sektor ini dilakukan pemerintah agar dapat meningkatkan kualitas SDM (Sumber Daya Manusia) yang ditunjukkan oleh IPM (Indeks Pembangunan Manusia). Sumber daya manusia yang baik akan mampu meningkatkan dan mendorong pembangunan ekonomi kearah yang lebih baik dan maju, sehingga pada akhirnya pembangunan ekonomi yang maju tersebut akan mengurahi jumlah kemiskinan dan melepaskan masyarakat miskin dari jeratan kemiskinan.

Dari pernyataan teori di atas sangat berbeda dengan kenyataan yang kita alami dan lihat sekarang bila kita bandingkan antara pengeluaran pemerintah terutama sektor pendidikan dan kesehatan dan juga pertubuhan ekonomi terhadap 
kemiskinan di provinsi aceh sebagaimana tingkat kemiskinan masih mengalami kenaikan.

Pada Tabel.1 di bawah ini dalam 7 Tahun terakhir kita bisa melihat persentase jumlah kemiskinan di Provinsi Aceh bila kita bandingkan dengan persentase pertumbhan ekonomi dan pengeluaran pemerintah di sektor pendidikan dan kesehatan di Provinsi Aceh yang saling bertolak belakang yang kurang sesuai dengan teori. Pengeluaran pemerintah sektor pendidikan dan kesehatan mengalami kenaikan setiap tahunnya begitu juga dengan kemiskinan mengalami kenaikan dan penurunan, sedangkan bila kita lihat pada tahun 2014 pertumbuhan ekonomi meningkat dan kemiskinan juga mengalami peningkatan.

\section{Tabel 1.1}

\section{Pertumbuhan Ekonomi, Pengeluaran}

Pemeintah di Sektor Pendidikan dan Kesehatan dan Kemiskinan di Provinsi Aceh

\begin{tabular}{|c|c|c|c|}
\hline Tahun & $\begin{array}{c}\text { Pertumbu } \\
\text { han } \\
\text { Ekonomi } \\
(\boldsymbol{\%})\end{array}$ & $\begin{array}{c}\text { Pengeluaran } \\
\text { Pemerintah } \\
\text { (Milyar) }\end{array}$ & $\begin{array}{c}\text { Kemiskinan } \\
(\boldsymbol{\%})\end{array}$ \\
\hline 2010 & 5,43 & 2825857,39 & 20,98 \\
\hline 2011 & 5,98 & 2955353,7 & 19,57 \\
\hline 2012 & 4,95 & 3131947,33 & 19,46 \\
\hline 2013 & 4,15 & 3257348,01 & 17,60 \\
\hline 2014 & 6,72 & 3329856,15 & 18,05 \\
\hline 2015 & 8,73 & 3419789,65 & 17,08 \\
\hline 2016 & 3,40 & 3497198,67 & 16,73 \\
\hline
\end{tabular}

Sumber Data : BPS Aceh, Aceh dalam angka

Dengan adanya tabel 1 dapat kita simpulkan dan baca bahwa Pengeluaran Pemerintah yang hampir setiap tahunnya mengalami kenaikan tetapi berbeda dengan pertumbuhan ekonomi yang mengalami kenaikan dan penurunan, disini yang menjadi permasalahan, pada tahun 2014 pertumbuhan ekonomi mengalami kenaikan $6,72 \%$ dari tahun sebelumnya yaitu pada tahun 2013 4,15\% dan juga diikuti dengan kemiskinan yang mengalami kenaikan juga pada tahun 2014 18,05\% dari tahun sebelumnya yaitu tahun 2013 17,60\%, dan kita ketahui bahwa pertumbuhan ekonomi bisa mengurangi kemiskinan atau pertumbuhan ekonomi belum begitu berperan untuk mengurangi tingkat kemiskinan dalam daerah tersebut.

Dalam upaya untuk meningkatkan pembangunan ekonomi, pemerintah telah meningkatkan pembangunan SDM (Sumber DayaManusia). Hal ini terwujud nyatadalam bentuk alokasi yang dikeluarkan oleh pemerintah pada sektor pendidikan dan kesehatan.

Dari permasalahan yang terjadi diatas, peneliti tertarik mengambil penelitian ini dengan judul "Pengaruh Pertumbuhan Ekonomi, Pengeluaran Pemerintah di Sektor Pendidikan dan Kesehatan Terhadap Kemiskinan di Provinsi Aceh".

\section{TINJAUAN TEORITIS}

\section{Kemiskinan}

Menurut (Todaro,2004) Kemiskinan merupkan salah satu masalah dasar dan menjadi pusat perhatian pemerintah di Negara manapun. Hampir di semua Negara berkmbang, standar hidup dari sebagian besar penduduknya cendrung sangat minim, jika dibandingkan dengan standar hidup orang-orang di Negara maju, atau dengan golongon elit di Negara mereka sendri. Standar hidup yang rendah tersebut terbentuk dalam wujud tingkat pendapatan yang rendah atau kemiskinan.

Kemiskinan juga sebuah permasalahan yang sifatnya mult dimensional. Pengertian secara umum yang biasanya digunakan dalam perhitungan dan kajian-kajian akademik adalah pegertian kemiskinan yang diperkenalkan oleh Bank Dunia yaitu sebagai ketidak sanggupan mencapai kebutuhan dan standar hidup minimum.

\section{Pertumbuhan Ekonomi}

Menurut (Sukirno, 2005) Pertumbuhan ekonomi dipengruhi oleh dua factor utama, yaitu pertumbuhan output total dan pertumbuhan penduduk.

Laju pertumbuhan ekonomi sangat dipengruhi oleh tergantung pada faktor-faktor produksi. Unsur pokok dari factor produksi suatu Negara ada tiga, yaitu :produktivitas sektor-sektor dalam menggunakan faktor-faktor produksinya, produktivitas dapat ditingkatkan melalui berbagai sarana pendidikan, pelatihan dan manajemen yang lebih baik.

Menurut teori pertumbuhan klasik, pertumbuhan ekonomi Sumberdaya alam merupkan wadah paling dasar dari kegiatan produksi suatu masyarakat dimna jumlah sumberdaya alam yang tersedia memiliki batas maksimal bagi pertumbuhan suatu perekonomian. Sumberdaya insane (jumlah penduduk) merupakan peran pasif dalam proses petumbuhan output, maksudnya jumlah akan menyesuaikan dengan kebutuhan akan tenga kerja. 


\section{METODE PENELITIAN}

Objek penelitian ini adalah Pertumbuhan Ekonomi, pengeluaran pemerintah di sektor pendidikan dan keshatan terhadap kemiskinan.

Dalam peneltian ini data diperoleh dari Badan Pusat Statistik (BPS) Provinsi Aceh dari tahun 2010-2016.

Defenisi Operasional Variabel dalam penelitian ini adalah sebagai berikut:

1. Pertumbuhan Ekonomi

Pertumbuhan ekonomi merupakan peningkatan kegiatan ekonomi yang dilakukan masyarakat yang akan membuat kenaikan produksi barang dan jasa atau meningkatkan pendapatan nasional yang diukur dalam persen.

2. Pengeluaran Pemerintah adalah kebijakan oleh pemerintah mengatur suatu perekonomian dengan menentukan besarnya penerimaan dan pengeluaran pemerintah setiap tahunnya yang dilogkan sehingga sampai jadi persen.

3. Kemiskinan

Kemiskinan dapat didefenisikan sebagai keadaan masyarakat atau penduduk yang masih kekurang atau belum bisa mencukupi kebutuhan sehari-hari dalam kehidupannya diukur dalam persen.

\section{Metode Analisis Data}

Metode analisis data yang digunkan dalam penelitian ini adalah metode kuantitatif yaitu pengambilan data secara statistik untuk mempermudah perhitungan dengan menggunakan data-data statistik. Untuk mengukur Pertumbuhan Ekonomi, Pengluaran Pemerintah di Sektor Pendidikan dan Keshatan yang mempengaruhi Kemiskinan di Aceh, digunakan model regresi linier berganda dengan bantuan program Eviews 9. Penggunaa regresi linier berganda dilakukan berdasarkan asumsi dasar bahwa kemiskinan ditentukan oleh tiga variabel bebas yaitu Pertumbuhan Ekonomi, Pengeluaran Pemerintah di Sektor Pendidikan dan Kesehatan. Adapun formula regresi linier berganda dalam penelititian ini adalah sebagai berikut :

$$
\mathrm{KMKN}=\beta 0+\beta_{1} \mathrm{PE}+\beta_{2} \operatorname{LogPENG}+e
$$

Keterangan:

$\begin{array}{lll}\text { KMKN } & =\text { Kemiskinan } \\ \beta 0 & =\text { Konstanta } \\ \beta_{1} & =\text { Koefisien Regresi Variabel PE } \\ \beta_{2} & =\text { Koefesien Regresi Variabel PENG } \\ \mathrm{PE} & =\text { Pertumbuhan Ekonomi } \\ \text { PENG } & =\text { Pengeluaran Pemerintah Sektor } \\ & \text { Pendidikan dan Kesehatan. } \\ \mathrm{e} & =\text { Variabel Gangguan }\end{array}$

\section{HASIL PENELITIAN DAN PEMBAHASAN}

\subsection{Hasil Penelitian}

Hasil Regresi Linier Berganda

\section{Variabl}

e Coefficient Std. Error t-Statistic Prob.

\begin{tabular}{crrrr}
\hline \hline & & & & \\
C & 22.74418 & 2.285614 & 9.951016 & 0.0000 \\
PE & $-\mathbf{- 0 . 0 0 5 4 2 2}$ & 0.026721 & -0.202918 & 0.8397 \\
LOG(P & & & & \\
ENG) & -1.696604 & 0.183201 & -9.260904 & 0.0000
\end{tabular}

Dari hasil perhitungan statistik diatas dapat dilihat persamaan hasil regresi bergandanya sebagai berikut:

\section{LOG(PENG)}

$\mathrm{KMKN}=22.7441-0.0054 \mathrm{PE}-1.6966$

Dari formula diatas menunjukkan bahwa nilai konstanta mempunyai nilai sebesar 22.7441 yang berarti bahwa bila variabel - variabel PE dan PENG tidak ada atau 0. Maka Tingkat Kemiskinan di Provinsi Aceh adalah sebesar $22.7441 \%$. Koefisien PE adalah sebesar 0.0054 yang berarti apabila PE meningkat sebesar 1\%, maka Kemiskinan di Provinsi Aceh akan menurun sebesar $0.0054 \%$ dengan asumsi variabel lain dianggap tetap. Sedangkan koefisien PENG sebesar 1.6966 yang berarti apabila PENG meningkat sebesar 1\%, maka kemiskinan di Provinsi Aceh akan menurun sebesar 1.6966\%.

\section{Hasil Parsial (Uji t)}

Pengujian hipotesis dapat dilakukan dengan menggunakan uji parsial (uji t). Dimana uji parsial digunkan untuk mengetahui apakah variabel-variabel indepnden secara parsial berpengaruh atau tidak terhdap variabel dependen, dengan membandingkan nilai $\mathrm{T}_{\text {Hitung }}$ dengan nilai

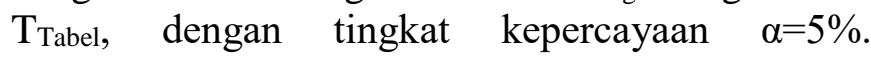
Pengujian yang digunakan dengan kriteria apabila 
$\mathrm{T}_{\text {Hitung }}>\mathrm{T}_{\text {Tabel }}$ pada $\alpha=5 \%$ maka artinya variabel bebas berpeengaruh signifikan terhadap variabel terikat. Apabila $\mathrm{T}_{\text {Hitung }}<\mathrm{T}_{\text {Tabel }}$ pada $\alpha=5 \%$ maka artinya variabel bebas tidak berpengaruh terhadap variabel terikat. variabel $\mathrm{PE}$ (Pertumbuhan Ekonomi) memiliki T $T_{\text {Hitung }}$ sebesar 0.202918 dengan nilai probabilitas statistiknya 0.8389 dan nilai $\mathrm{T}_{\text {Tabel }}(\mathrm{df})=\mathrm{n}-\mathrm{k}(7-3=4)$ pada $\alpha=5 \%$ diperoleh nilai sebesar 2.13185. Maka dapat disimpulkan bahwa $\quad \mathrm{T}_{\text {Hitung }}<\mathrm{T}_{\text {Tabel }}$ yaitu $0.202918<2.13185$, dengan probabilitas $0.8389>0.05 \%$. Maka diperoleh keputusan yang berarti secara parsial PE (Pertumbuhan Ekonomi) tidak berpengaruh terhadap KMKN (kemiskinan) di Provinsi Aceh.

PENG (Pengeluaran Pemerintah) memiliki $\mathrm{T}_{\text {Hitung }}$ sebesar 9.260903 dengan nilai probabilitas nya sebesar 0.0000 , dan nilai $\mathrm{T}_{\text {Tabel }}$ dengan $(\mathrm{df})=\mathrm{n}-\mathrm{k}(7-3=4)$ pada $\alpha=5 \%$ diperoleh nilai sebesar 2.13185. Maka dapat disimpulkan $\mathrm{T}_{\text {Hitung }}>\mathrm{T}_{\text {Tabel }}$ yaitu $9.260903>2.13185$, dengan probabilitas $0.0000<0.05$. Dari hasil tersebut diperoleh keputusan berarti secara parsial PENG (Pengeluaran Pemerintah) berpengaruh secara signifikan terhadap KMKN (Kemiskinan) di Provinsi Aceh.

\section{Secara Simultan (Uji f)}

Uji F dilakukan untuk mengtahui apakah variabel-variabel Independent secara serempak (bersama-sama) mempengaruhi variabel dependent. Apabila nilai $\mathrm{F}_{\text {Hitung }}>\mathrm{F}_{\text {Tabel }}$ maka variabel-variabel independent secara serempak berpngaruh terhadap variabel dependent. Sebaliknya apabila $\mathrm{F}_{\text {Hitung }}<\mathrm{F}_{\text {Tabel }}$ maka variabelvariabel independent secara serempak tidak berpengaruh terhadap variabel dependent. Dalam Uji ini dapat dilihat dimana $F_{\text {Hitung }}$ sebesar 1750.028 dengan probabilitas sebesar 0.000000 pada tingkat kepercayaan $95 \%$. Pada $\mathrm{F}_{\text {Tabel }}(\mathrm{dfl})=\mathrm{k}$ $1 \quad(3-1=2)$ dan $(\mathrm{df})=\mathrm{n}-\mathrm{k} \quad(7-3=4)$ diperoleh nilai sebesar 6.94 pada $\alpha=0.05(5 \%)$. Dari hasil tersebut dapat dilihat dimana $\mathrm{F}_{\text {Hitung }}>\mathrm{F}_{\text {Tabel }}$ atau $1750.028>6.94$ dengan nilai probabilitas $0.000000<0.05 \%$. Maka diperoleh keputusan berarti secara serempak PE (Pertumbuhan Ekonomi) dan PENG (Pengeluaran Pemerintah di Sektor Pendidikan dan Kesehatan) berpengaruh secara signifikan terhadap KMKN (kemiskinan) di Provinsi Aceh.

\section{Uji Koefesien Determinasi $\left(\mathbf{R}^{\mathbf{2}}\right)$}

Koefisien determinasi $\left(\mathrm{R}^{2}\right)$ digunakan untuk mengetahui seberapa besar variabel-variabel independent mampu mempengaruhi variabel dependent nya. Berdasarkan tabel 4.4 diketahui koefisien determinasi $\left(\mathrm{R}^{2}\right)$ dilihat dari Adjusted $R$ squared yaitu sebesar: 0.990598 yang artinya pengaruh variabel pertumbuhan ekonomi (PE) dan pengeluaran pemerintah di sektor penddikan dan keshatan (PENG) terhadap variabel Kemiskinan (KMKN) di Provinsi Aceh telah mampu dijelaskan sebesar 99\%. Sementara sisanya yaitu $0.94(1 \%)$ dipengaruhi oleh variabel lainnya yang tidak dimasukkan dalam peneltian ini.

\subsection{Pembahasan}

\section{Pengaruh Pertumbuhan Ekonomi Terhadap Kemiskinan di Provinsi Aceh}

Berdasarkan hasil pengujian bahwa

Pertumbuhan Ekonomi tidak berpngaruh secara positif dan signifikan terhdap kemiskinan di Provinsi Aceh tahun 2010-2016. Dan pengaruh dari Pertumbuhan ekonomi terhadap kemiskinan bertanda negatif, menyatakan bahwa bentuk pengaruh antara pertumbuhan ekonomi terhadap kemiskinan adalah berbanding terbalik, yang berarti bahwa peningkatan faktor Pertumbuhan ekonomi sebesar 1 persen, akan menurunkan kemiskinan sebesar $0.0054 \%$. Tetapi dalam penelitian ini, uji yang dilakukan pengaruhnya tidak signifikan, artinya Pertumbuhan ekonomi tidak begitu mempengaruhi kemiskinan. Hasil penelitian ini tidak sesuai dengan penelitian yang dilakukan oleh siregar dan (Winarti, 2006) yang menyimpulkan bahwa kenaikan pertumbuhan ekonomi mengakibatkan penurunan atas angka kemiskinan. Namun, Penelitian ini sesuai dengan temuan dari World Bank (2006) dalam Wahyudi (2010) yang menyatakan bahwa pertumbuhan ekonomi belum dapat secara signifikan mengurangi kemiskinan, dikarenakan pola dari pertumbuhan ekonomi yaitu terjadinya ketimpangan, Karena bisa kita lihat dalam data 2010-2016 juga sebagaimana pada tahun 2014 pertumbuhan ekonomi mengalami kenaikan 6,73 dari tahun sebelumnya tahun 2013 yaitu 4,15\%, begitu juga kemiskinan pada tahun 2014 mengalami kenaikan $18,05 \%$ dari pada tahun sebelumnya tahun 2013 yaitu $17,60 \%$.

Penelitian ini sesuai dengan penelitian yang dilakukan oleh (Hartati, 1015) di Kabupaten Jayapura Tahun 2016-2013. Pertumbuhan ekonomi tidak berpengaruh secara positif dan signifikan terhadap kemiskinan, dikarenakan pola dari pertumbuhan ekonomi yaitu terjadi ketimpangan. 
Pengaruh Pengeluaran Pemerintah di Sektor Pendidikan dan Kesehatan Terhadap Kemisknan di Provinsi Aceh

Berdasarkan hasil pengujian bahwa Pengeluaran Pemerintah di Sektor Pendidikan dan Kesehatan berpengaruh secara signifikan terhadap pertumbuhan kemiskinan tahun 2010-2016. Secara garis besar, alokasi pengeluaran pemerintah di sektor pendidikan dan kesehatan di Provinsi Aceh menunjukkan kecenderungan yang meningkat. signifikanya pengruh pengluaran pemrintah di sektor pendidikan dan kesehtan kita bisa melihat juga dalam persentasi data tahun 2010-2016 sebagaiman pengeluaran pemerintah mengalami kenaikan setiap tahunya yang mampu menurunkan kemiskinan dari tahun 2010 yaitu 20,98\% ke tahun 2016 yaitu $16,73 \%$.

Penelitian ini sesuai dengan penelitian Desmawan (2016) di Provinsi Lampung. Pengluaran pemeritah di sektor pendidikan dan kesehtan berpngaruh secara signfikan terhdap kemiskinan dengan koefesien regresi sebesar 0.00127. Dasar teori juga mengikuti (Winarto, 2011) yang menyatakan bahwa pengeluaran pemerintah pada sektor pendidikan dan kesehatan merupakan komposisi yang diperlukan dalam meningkatkan sumber daya mansia yang berkualitas sehingga mampu mendorong pembangunan perekonomian yang baik dan dapat mengurangi kemiskinan.

\section{KESIMPULAN DAN SARAN Kesimpulan}

Berdasarkan hasil penelitian yang telah dilakukan, maka diperoleh kesimpulan sebagai berikut:

1. Berdasarkan uji asumsi klasik yang telah dilakukan baik Multikolinieritas, Autokorelasi dan pada data yang digunakan terbebas dari indikasi uji asumsi klasik atau tidak terjadi masalah uji asumsi klasik.

2. Secara parsial menyatakan bahwa variabel Pertmbuhan Ekonomi tidak berpngaruh secara positif dan signfikan terhadap Kemiskinan di Provinsi Aceh, dan Pengluaran Pemerntah di Sektor Pendidikan dan Kesehatan berpngaruh secara negatif dan signfikan terhadap kemiskinan di Provinsi Aceh tahun 20102016.
3. Secara simultan menyatakan bahwa variabel Pertmbuhan Ekonomi dan Pengeluaran Pemerntah di Sektor Pendidkan dan Kesehtan secara bersamasama atau serempak berpengaruh terhadap pertumbuhan ekonomi di Aceh tahun 20102016.

\section{Saran}

Berdasarkan hasil penelitian dan kesimpulan diatas, penulis memberikan saran sebagai berikut:

1. Bagi pemerintah Aceh disarankan agar lebih memperhatikan Pertumbuhan Ekonomi dan Pengeluaran Pemerintah terutama di Sektor Pendidikan dan Kesehatan yang terjadi di Provinsi Aceh, terutama kemiskinan, sebaiknya pemerintah mengambil keputusan untuk mengurangi tingkat kemiskinan yang terjadi di Aceh.

2. Pertumbhan ekonomi yang meningkat diharapkan dapat menurunkan kemiskinan, memperbaiki keadaan perekonomian di Aceh serta memperbaiki kualitas sumber daya manusianya melalui pendidikan.

3. Untuk penelitian selanjutnya, diharapkan lebih mampu menjelaskan kondisi pertubuhan ekonomi, pengeluaran pemerintah di sektor pendidkan dan kesehtan dan salah satunya faktor apa yang mempengaruhi kemskinan di Provinsi Aceh.

\section{DAFTAR PUSTAKA}

Hartati, Evi. (2015. Analisis Pengaruh Pertumbuhan Ekonomi Dan Pengangguran Terhadap Tingkat Kemiskinan Di Kabupaten Jayapura.

Kuncoro, Mudrajat. (2004).Ekonomi PembangunanTeori, Masalah, DanKebijakan. UPPAMPYKPN. Yogyakarta.

Kuncoro. (2006).Ekonomi

Pembangunan;Proses,Masalah, dan DasarKebijakan.

KencanaPrenadaMediaGroup. Jakarta. 
Kuncoro. (2007). Ekonomi Pembangunan :

Teori, Masalah Kebijakan,Edisi

Ketiga.Yogyakarta : UPP AMP YKPN.

Mankiw, N.Gregory. (2007). Makroekonomi.

Jakarta : Erlangga

Sukirno, Sadono. (2000). Makro Ekonomi

Modern : Perkembangan Pemikiran dari Klasik sampai Keynesian.

Lembaga Penerbit FE-UI.Jakarta.

Sukirno, Sadono. (2005). Ekonomi

Pembangunan (Proses, Makalah, dan

Dasar Kebijakan),Jakarta : Kencana

Sukirno, Sadono. (2006).Ekonomi

Pembangunan;Proses,Masalah, dan

DasarKebijakan.

KencanaPrenadaMediaGroup. Jakarta.

Sukirno, Sadono. (2008), Ekonomi

Pembangunan (Proses, Masalah, dan

Dasar Kebijakan),Jakarta : Fakultas

Ekonomi UI.

Sudiyono. (2004).Manajemen Pendidikan

Tinggi. Jakarta: PT Rineka Cipta.

Suryawati. (2005). Analisis Pengaruh PDRB,

Tingkat Investasi dan Tingkat

Angkatan Kerja Terhadap

Kemiskinan di Sumatera Utara.

Soediyono. (1996). Ekonomi Makro, Pengantar

Analisis

Pendapatan

Nasional.Yogyakarta : Erlangga

Todaro. (2004). Analisis Pengaruh Sektor

Pertanian, Sektor Industri Pengolahan

Terhadap Kemiskinan di Jawa

Tengah.Universitas Padjajaran.

Todaro Michael P dan Smith Stephen C. (2006),

Pembangunan Ekonomi Edisi ke-

9,Penerbit Erlangga 